\title{
Anna Szymańska* \\ THE APPLICATION OF BÜHLMANN-STRAUB MODEL TO THE ESTIMATION OF NET PREMIUM RATES DEPENDING ON THE AGE OF THE INSURED IN THE MOTOR HULL LIABILITY INSURANCE
}

\begin{abstract}
One of the basic variables used in the process of tariff calculation of premiums in motor hull liability insurance is the age of the insured. In this type of insurance offered by insurers operating on the Polish market, this variable is taken into account in the ratemaking by discounts and increases in assigned premium, known as the net premiums rates. The aim of this work is to propose a method of rate estimation of net premiums in the groups of the motor hull liability insurance portfolio of individuals created by the age of the insured. For the premium estimation one of the maximum likelihood models, called the Bühlmann-Straub model was used.
\end{abstract}

Keywords: a posteriori ratemaking, credibility theory, motor hull liability insurance

JEL: C11, G22, C51

\section{INTRODUCTION}

In motor hull liability insurance the process of premium calculation consists of two stages. The first, called a priori ratemaking is the determination of net premiums, using actuarial methods (Antonio, Valdez 2012) based on certain risk factors, known as the basic ratemaking variables. The premium so defined increased, among others, by the costs of insurance operations and the security addition is known as the base premium. The second stage of ratemaking is a posterior ratemaking, consisting in the base premium increases and discounts depending on individual risk factors of the insured. One of the components of the posterior ratemaking, commonly used in Europe, are the bonus-malus systems. The bonus-malus systems (Lemaire 1995) differentiate the premium, with respect to the number of claims reported by the insured in the previous insurance period, which is based on the damage history of the insured. In addition to the bonus-malus system insurance companies may use other discounts and increases in the premium dependent on additional ratemaking variables, such as the age of the insured, the period of driving license holding, profession of the insured, the age and brand of the car, using car for business

\footnotetext{
* Ph. D., Department of Statistical Methods, University of Łódź.
} 
purposes, having or not any other insurance with the same company, continuation of insurance and so on. Competition on the insurance market should force the insurers to use different ratemaking variables in the ratemaking process to match premiums to the risk, represented by the insured, which should lead to lower premiums especially for those insured who do not cause damage. In Europe, additional variables most often used in ratemaking are the age of the insured, the use of the vehicle for commercial purposes and car age. In Poland increase for the insured under the age of 25 years is as high as $300 \%$ of the base premium. In some countries, such as France or Norway, the age is an element of the prior ratemaking. The aim of this paper is to present the method for determining the increases and discounts in the premium depending on the age of the insured on the basis of estimation of premiums by the credibility estimation method and evaluation of premium rates related to age applied in the audited insurance company. The author's proposition is to use the Bühlmann -Straub model for this purpose. An example of the application of the new method is presented based on the data obtained from one of the insurance companies operating on the Polish market, which has reserved the right to stay anonymous.

\section{CREDIBILITY PREMIUM}

Let $X_{i j}$ denote the total amount of claims paid (or the number of claims) for the $i$-th insured (the $i$-th sub-group) in the $j$-th year of insurance. Suppose that the insurer has observations $x_{i j}, i=1, \ldots, N, j=1, \ldots, t$, which are the realizations of random variables $X_{i j}$. The amounts of payments $x_{i, t+1}$ in year $t+1$ are not known.

Let us assume that for each $i$ the distribution of the random variable $X_{i j}$ depends on parameter $\theta_{i}$ and that random variables $X_{i j}$ by given $\Theta_{i}=\theta_{i}$ are independent and have the same distribution. Random vector $\mathbf{X}_{i}=\left(X_{i 1}, \ldots, X_{i t}\right)$ denotes the individual history of insurance for the policy $i$ (i-th sub-group) in a portfolio consisting of $N$ policies (subgroups). The aim of the insurer is to determine the net premium in the year $t+1$ for the contract and the ( $i$-th sub-group), given the vector $\mathbf{x}_{i}=\left(x_{i 1}, \ldots, x_{i t}\right)$.

Assuming the equivalence of claims and premiums - net premium $m\left(\theta_{i}\right)$ for contract $i$ ( $i$-th sub-group) is defined by the formula:

$$
m\left(\theta_{i}\right)=E\left(X_{i, t+1} \mid \Theta_{i}=\theta_{i}\right)
$$

Since we do not know $\theta_{i}$ parameter value, the value of net contributions is unknown. 
The premium calculated as a weighted average from the premium for the entire portfolio, i.e. collective premiums $\mu=E X_{j}$ and individual premium $\bar{x}_{i}=\frac{1}{t} \sum_{j=1}^{t} x_{i j}$ in the form:

$$
m\left(\theta_{i}\right)=Z_{i} \bar{x}_{i}+\left(1-Z_{i}\right) \mu
$$

is called a credibility premium for the the $i$-th contract (the $i$-th sub-group), where $Z_{i} \in[0,1]$ is a credibility factor (Kowalczyk, Poprawska, RonkaChmielowiec 2006).

The estimator of variable $X_{i, t+1}$ is called a predictor of this variable, while the predictor's value is called a forecast for $X_{i, t+1}$ based on observations $x_{i 1}, \ldots, x_{i t}$. The basis of the credibility theory is the Bayesian statistical analysis with quadratic loss function (Krzyśko 1996).

One of the tasks of the credibility theory is to determine the of values of the credibility $Z_{i}$ factor. A small value of the coefficient means that the collective premium is more credible for the insurer than individual premium. The factor $Z_{i}$ is approximately equal to one when the history of damage to the policy or a group policy is long and has small variation with respect to time or when contracts (group of policies) are very different from one another in terms of the history of damage.

\section{BÜHLMANN-STRAUB MODEL}

Historically, the first model of the credibility theory was the Bühlmann model (Bühlmann 1967), in which it is assumed that the portfolio policies can be divided into $N$ sub-groups, each of which contains the same number of policies for which the data on $t$ damage periods is available.

The Bühlmann-Straub model is a modified Bühlmann model, in which the number of policies included in the portfolio of individual subgroups does not have to be equal and which takes into account the importance of contracts in the portfolio. Also, the number of policies may vary periodically (Denuit, Marechal, Pitrebois, Walhin 2007).

The model finds its application especially when a single policy or a small subset of policies differs significantly, in terms of risk profile, from the others. It is a one-way classification model. The model takes into account the weights (i.e. the volume of risk) $w_{i j}$ of random variables $X_{i j}$. If the random variable $X_{i j}$ denotes the arithmetic average of $w_{i j}$ independent random variables with the same distributions, then the numbers $w_{i j}$ are natural weights. The actuary, 
however, may establish its own weights, which do not have to be integers. In this model, insurance histories may have different lenghts $t_{i}$ for different contracts $i$. The structure of the data in the model are presented in table 1 (Jasiulewicz 2005).

Table 1. Structure of data in the Bühlmann-Straub model

\begin{tabular}{|c|c|c|c|c|}
\hline \multirow{2}{*}{$\begin{array}{c}\text { Groups } \\
\text { of policies }\end{array}$} & \multicolumn{4}{|c|}{ Years of insurance } \\
\cline { 2 - 5 } & 1 & 2 & $\ldots$ & $t$ \\
\hline \multirow{2}{*}{1} & $x_{11}$ & $x_{12}$ & $\ldots$ & $x_{1 t}$ \\
& $w_{11}$ & $w_{12}$ & $\cdots$ & $w_{1 t}$ \\
\hline \multirow{2}{*}{2} & $x_{21}$ & $x_{22}$ & $\ldots$ & $x_{2 t}$ \\
& $w_{21}$ & $w_{22}$ & $\ldots$ & $w_{2 t}$ \\
\hline$\ldots$ & $\ldots$ & $\ldots$ & $\ldots$ & $\ldots$ \\
\hline \multirow{2}{*}{$N$} & $x_{N 1}$ & $x_{N 2}$ & $\ldots$ & $x_{N t}$ \\
& $w_{N 1}$ & $w_{N 2}$ & $\ldots$ & $w_{N t}$ \\
\hline
\end{tabular}

Source: Jasiulewicz 2005.

As previously assigned, let $\mathbf{X}_{i}=\left(X_{i 1}, \ldots, X_{i t}\right)$ be a vector of observation of the number of damages for $i$-th policy ( $i$-th subgroup of policies) during last $t$ years, and let random variable $\Theta_{\mathrm{i}}$, represent the structure of risk in portfolio.

The assumptions of the Bühlmann-Straub model (Bühlmann, Straub 1970):

1. For given $i$ and $\Theta_{\mathrm{i}}=\theta_{i}$, random variables $X_{i 1}, \ldots, X_{i t}$ are independent and

$$
\begin{gathered}
\mathrm{E}\left(X_{i j} \mid \theta_{i}\right)=m\left(\theta_{i}\right), \\
\operatorname{Var}\left(X_{i j} \mid \theta_{i}\right)=\frac{s^{2}\left(\theta_{i}\right)}{w_{i j}}
\end{gathered}
$$

for $i=1, \ldots, N, j=1, \ldots, t$, wherein variables $w_{i j}$ are known.

2. Pairs $\left(\Theta_{1}, \boldsymbol{X}_{1}\right), \ldots,\left(\Theta_{N}, \boldsymbol{X}_{N}\right)$ are mutually independent and random variables $\Theta_{1}, \ldots, \Theta_{N}$ are independent and have the same distributions.

Let there be given:

- the average amount of damages for the $i$-th sub-group of policies:

$$
\bar{X}_{i w}=\sum_{j=1}^{t} \frac{w_{i j}}{w_{i}} X_{i j}, \quad w_{i}=\sum_{j=1}^{t} w_{i j},
$$

- the average amount of damage for the portfolio:

$$
\bar{X}_{w w}=\sum_{i=1}^{N} \frac{w_{i}}{w} \bar{X}_{i w}, \quad w=\sum_{i=1}^{N} w_{i},
$$


- structural parameters of risk in portfolio:

$$
\mu=E m\left(\Theta_{i}\right)=E X_{i j}, \quad \varphi=E s^{2}\left(\Theta_{i}\right), \quad \psi=\operatorname{Var}\left(m\left(\Theta_{i}\right)\right),
$$

where:

$\mu$ - collective net premium, which is a weighted average of the individual net premiums $m\left(\theta_{i}\right)$; the overall mean, it is the expected value of the claim amount for an arbitrary policyholder in the portfolio,

$\varphi$ - describes the average volatility of claims in a group (variation within the group),

$\psi-$ describes the variation of claims between groups.

It can be proved that if the assumptions of the Bühlmann-Straub model are met, then (Kass, Goovaerts, Dhaene, Denuit 2001):

1. Best inhomogeneous linear predictor $\tilde{m}_{i}=E\left(X_{i n+1} \mid \mathbf{X}_{i}\right)$ of the risk premium $m\left(\Theta_{i}\right)$ in the sense of least mean square error is of the form:

$$
\tilde{m}_{i}=Z_{i} \bar{X}_{i w}+\left(1-Z_{i}\right) \mu
$$

where the trust factor is $Z_{i}=\frac{w_{i} \psi}{w_{i} \psi+\varphi}$

2. Best inhomogeneous linear predictor $\widetilde{m}_{i}^{*}$ of net premium $m\left(\Theta_{i}\right)$ in the sense of least mean square error is of the form:

$$
\tilde{m}_{i}^{*}=Z_{i} \bar{X}_{i w}+\left(1-Z_{i}\right) \bar{X}_{z w}
$$

where the trust factor is $Z_{i}=\frac{w_{i} \psi}{w_{i} \psi+\varphi} \quad$ and $\quad \bar{X}_{z w}=\sum_{i=1}^{N} \frac{Z_{i}}{Z} \bar{X}_{i w}$, $Z=Z_{1}+\ldots+Z_{N}$.

It can be proved that if the assumptions of the Bühlmann-Straub model are met, then unbiased estimators of structural parameters in the portfolio are of the form (Kass, Goovaerts, Dhaene, Denuit 2001):

$$
\hat{\mu}=\bar{X}_{z w}, \hat{\varphi}_{N}=M S W, \hat{\psi}=\frac{w(N-1)(M S B-M S W)}{w^{2}-\sum_{i=1}^{N} w_{i}^{2}},
$$


where:

$$
S S W=\sum_{i=1}^{N} \sum_{j=1}^{t} w_{i j}\left(X_{i j}-\bar{X}_{i}\right)^{2}-\text { the weighted sum of squares of deviations }
$$

within groups (sum-of-squares-within);

$M S W=\frac{S S W}{(t-1) N}-$ the average weighted sum of squares of deviations within groups (mean-square-within);

$S S B=\sum_{i=1}^{N} w_{i}\left(\bar{X}_{i w}-\bar{X}_{w w}\right)^{2}-$ the weighted sum of squares of deviations between groups (sum-of-squares-between);

$M S B=\frac{S S B}{N-1}-$ the average weighted sum of squares of deviations between groups (mean-square-between).

If the assumptions of the Bühlmann-Straub model are met, the average square error of homogenous and inhomogeneous predictor of credibility premium $m\left(\Theta_{i}\right)$ are respectively (Daykin, Pentikäinen, Pesonen 1994):

$$
\begin{gathered}
M S E_{i}=E\left(m\left(\Theta_{i}\right)-\tilde{m}_{i}\right)^{2}=\left(1-Z_{i}\right) \psi \\
M S E_{i}^{*}=E\left(m\left(\Theta_{i}\right)-\widetilde{m}_{i}^{*}\right)^{2}=\left(1-Z_{i}\right) \psi\left(1+\frac{1-Z_{i}}{Z}\right)
\end{gathered}
$$

for $i=1, \ldots, N$.

\section{EXAMPLE}

Empirical research was carried out based on the data from the portfolio of the motor hull liability insurance of motor vehicle owners individuals from the period of four years. For the sake of the study more than 5000 policies were drawn for each year analyzed (the exact sample size is not specified due to the anonymity of the data). In what follows, this sample will be called portfolio. The data, in aggregated form, on the number and value of claims paid with respect to the age groups of the insured are presented in Tables 2 and 3. The division of the insured into age groups is consistent with the classification of the insurer. The set out number of claims and the division into classes according to the value of claims paid is consistent with ratemaking of the insurer. 


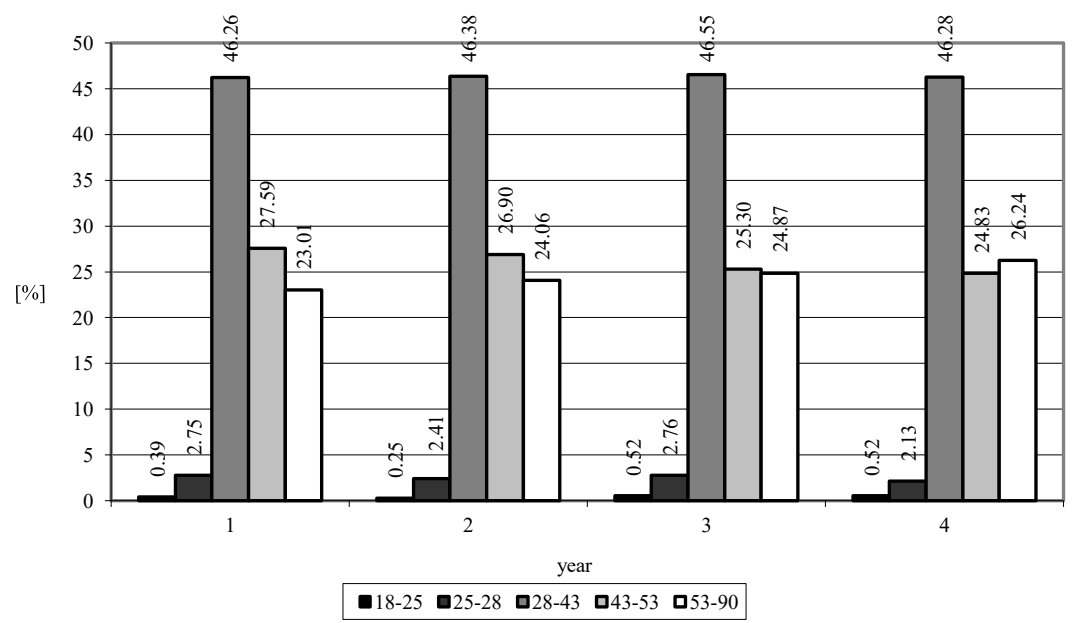

Figure 1 . The structure of insured by age and the number of claims paid in the motor hull liability insurance portfolio in the years analyzed [\%]

Source: developed by the author based on the data derived from the insurer.

In the years analyzed, people aged under 25 accounted for less than $1 \%$ of the insured in the analyzed portfolio. The largest group are the insured at the age of 28 to 43 years (approx. 46\%).

Table 2. The structure of insured by age and the number of claims paid in the motor hull liability insurance portfolio in the years analyzed [\%]

\begin{tabular}{|c|c|c|c|c|c|c|}
\hline \multirow{2}{*}{ Year } & \multirow{2}{*}{ Age } & \multicolumn{4}{|c|}{ Number of claims } & \multirow{2}{*}{ Portfolio } \\
\cline { 2 - 7 } & & 0 & 1 & 2 & 3 & \\
\hline 1 & 2 & 3 & 4 & 5 & 6 & 7 \\
\hline \multirow{4}{*}{1} & $18-25$ & 0.3050 & 0.0821 & 0.0000 & 0.0000 & 0.3872 \\
\cline { 2 - 7 } & $25-28$ & 2.3699 & 0.3481 & 0.0235 & 0.0078 & 2.7492 \\
\cline { 2 - 7 } & $28-43$ & 41.4493 & 4.3721 & 0.3793 & 0.0587 & 46.2594 \\
\cline { 2 - 7 } & $43-53$ & 24.7663 & 2.6123 & 0.1838 & 0.0274 & 27.5898 \\
\cline { 2 - 7 } & $53-90$ & 21.1763 & 1.7168 & 0.1056 & 0.0156 & 23.0144 \\
\cline { 2 - 7 } & $\sum$ & 90.0669 & 9.1314 & 0.6922 & 0.1095 & 100.0000 \\
\hline \multirow{4}{*}{2} & $18-25$ & 0.2102 & 0.0396 & 0.0000 & 0.0000 & 0.2498 \\
\cline { 2 - 7 } & $25-28$ & 2.0500 & 0.3116 & 0.0346 & 0.0173 & 2.4135 \\
\cline { 2 - 7 } & $28-43$ & 41.2795 & 4.6811 & 0.3685 & 0.0495 & 46.3785 \\
\cline { 2 - 7 } & $43-53$ & 24.0461 & 2.6262 & 0.1954 & 0.0346 & 26.9022 \\
\cline { 2 - 7 } & $53-90$ & 21.9442 & 1.9140 & 0.1682 & 0.0297 & 24.0560 \\
\cline { 2 - 7 } & $\sum$ & 89.5299 & 9.5724 & 0.7666 & 0.1311 & 100.0000 \\
\hline
\end{tabular}


Table 2 (cont.)

\begin{tabular}{|c|c|c|c|c|c|c|}
\hline 1 & 2 & 3 & 4 & 5 & 6 & 7 \\
\hline \multirow{4}{*}{3} & $18-25$ & 0.4297 & 0.0813 & 0.0100 & 0.0000 & 0.5210 \\
\cline { 2 - 7 } & $25-28$ & 2.3045 & 0.3998 & 0.0481 & 0.0116 & 2.7641 \\
\cline { 2 - 7 } & $28-43$ & 40.8973 & 5.0354 & 0.5077 & 0.1062 & 46.5465 \\
\cline { 2 - 7 } & $43-53$ & 22.5441 & 2.5169 & 0.2140 & 0.0249 & 25.2999 \\
\cline { 2 - 7 } & $53-90$ & 22.5773 & 2.0872 & 0.1626 & 0.0415 & 24.8685 \\
\cline { 2 - 7 } & $\sum$ & 88.7528 & 10.1206 & 0.9424 & 0.1842 & 100.0000 \\
\hline \multirow{4}{*}{4} & $18-25$ & 0.4243 & 0.0788 & 0.0145 & 0.0032 & 0.5208 \\
\cline { 2 - 7 } & $25-28$ & 1.8212 & 0.2716 & 0.0338 & 0.0048 & 2.1314 \\
\cline { 2 - 7 } & $28-43$ & 41.4479 & 4.3930 & 0.3761 & 0.0627 & 46.2797 \\
\cline { 2 - 7 } & $43-53$ & 22.2863 & 2.2889 & 0.2234 & 0.0305 & 24.8292 \\
\cline { 2 - 7 } & $53-90$ & 24.1155 & 1.9401 & 0.1575 & 0.0257 & 26.2389 \\
\cline { 2 - 7 } & $\sum$ & 90.0953 & 8.9724 & 0.8053 & 0.1270 & 100.0000 \\
\hline
\end{tabular}

Source: developed by the author based on the data derived from the insurer.

Figure 2 presents the mean number of claims paid in each age group in the years analyzed. The highest loss ratio of 0.15 to 0.23 in the studied period was observed in the group of under 25 years. Among the insured aged from 25 to 28 years there has been an annual average of 0.15 to 0.19 damages. It should be noted that in other age groups, the average number of claims submitted per year was smaller, it varied from 0.08 to 0.14 . The portfolio mean ranged from 0.11 to 0.13 .

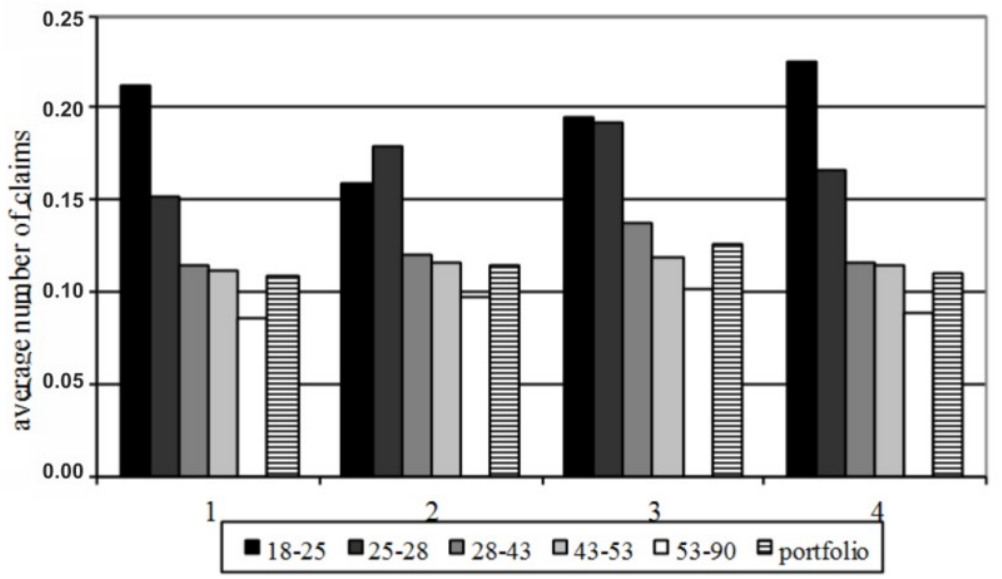

Figure 2. The average number of claims paid in the motor hull liability insurance portfolio in the years analyzed according to the insured age groups

Source: own elaboration. 
The Application of Bühlmann-Straub Model...

Table 3 . The structure of insured [in \%] by age and the value of claims paid in the motor hull liability insurance portfolio in the years analyzed

\begin{tabular}{|c|c|c|c|c|c|c|c|c|c|c|c|}
\hline \multirow[b]{2}{*}{ 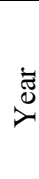 } & \multirow[b]{2}{*}{$\begin{array}{c}\text { Age } \\
\text { [years] }\end{array}$} & \multicolumn{9}{|c|}{ Value of claim [thousands of zlotys] } & \multirow[b]{2}{*}{$\begin{array}{l}\stackrel{0}{\circ} \\
\stackrel{0}{0} \\
\stackrel{0}{0}\end{array}$} \\
\hline & & $(0,1]$ & $(1,3]$ & $(3,5]$ & $(5,10]$ & $(10,20]$ & $(20,30]$ & $(30,40]$ & $(40,50]$ & $\begin{array}{l}(50, \\
100]\end{array}$ & \\
\hline \multirow{6}{*}{1} & $18-25$ & 0.16 & 0.20 & 0.12 & 0.24 & 0.04 & 0.08 & 0.00 & 0.00 & 0.00 & 0.83 \\
\hline & $25-28$ & 0.28 & 1.42 & 0.75 & 0.79 & 0.47 & 0.08 & 0.04 & 0.00 & 0.00 & 3.82 \\
\hline & $28-43$ & 5.91 & 17.24 & 9.72 & 10.35 & 3.86 & 0.75 & 0.43 & 0.08 & 0.08 & 48.43 \\
\hline & $43-53$ & 2.72 & 11.26 & 5.87 & 5.83 & 2.05 & 0.35 & 0.20 & 0.16 & 0.00 & 28.43 \\
\hline & $53-90$ & 2.05 & 7.05 & 3.62 & 3.50 & 1.57 & 0.51 & 0.16 & .04 & .00 & 18.50 \\
\hline & $\sum$ & 11.10 & 37.17 & 20.08 & 20.71 & 7.99 & 1.77 & 0.83 & 0.28 & 0.08 & 100.00 \\
\hline \multirow{6}{*}{2} & do 25 & 0.05 & 0.05 & 0.07 & 0.07 & 0.12 & 0.00 & 0.02 & 0.00 & 0.00 & 0.38 \\
\hline & $25-28$ & 0.33 & 1.09 & 0.66 & 0.73 & 0.45 & 0.17 & 0.00 & 0.02 & 0.02 & 3.47 \\
\hline & $28-43$ & 6.24 & 18.66 & 8.76 & 9.02 & 4.13 & 1.28 & 0.26 & 0.19 & 0.14 & 48.69 \\
\hline & $43-53$ & 3.66 & 10.73 & 4.84 & 5.13 & 2.27 & 0.47 & 0.12 & 0.07 & 0.00 & 27.29 \\
\hline & $53-90$ & 2.32 & 7.77 & 4.28 & 3.87 & 1.42 & 0.33 & 0.12 & 0.02 & 0.05 & 20.17 \\
\hline & $\sum$ & 12.59 & 38.29 & 18.62 & 18.83 & 8.39 & 2.24 & 0.52 & 0.31 & 0.21 & 100.00 \\
\hline \multirow{6}{*}{3} & do 25 & 0.12 & 0.28 & 0.09 & 0.15 & 0.12 & 0.04 & 0.01 & 0.00 & 0.00 & 0.81 \\
\hline & $25-28$ & 0.63 & 1.28 & 0.62 & 0.74 & 0.47 & 0.21 & 0.10 & 0.00 & 0.03 & 4.09 \\
\hline & $28-43$ & 7.02 & 19.38 & 8.97 & 8.72 & 4.25 & 1.11 & 0.41 & 0.24 & 0.13 & 50.23 \\
\hline & $43-53$ & 3.53 & 9.88 & 5.03 & 3.70 & 1.74 & 0.44 & 0.15 & 0.01 & 0.01 & 24.50 \\
\hline & $53-90$ & 2.95 & 7.32 & 4.28 & 4.07 & 1.43 & 0.22 & 0.09 & 0.00 & 0.01 & 20.37 \\
\hline & $\sum$ & 14.25 & 38.15 & 18.99 & 17.38 & 8.01 & 2.02 & 0.77 & 0.25 & 0.19 & 100.00 \\
\hline \multirow{6}{*}{4} & do 25 & & 0.36 & 0.19 & 0.10 & 0.19 & 0.02 & 0.00 & 0.00 & 0.00 & 0.97 \\
\hline & $25-28$ & 0.58 & 1.07 & 0.55 & 0.52 & 0.26 & 0.13 & 0.02 & 0.00 & 0.00 & 3.13 \\
\hline & $28-43$ & 7.35 & 17.87 & 9.01 & 8.44 & 4.01 & 1.33 & 0.47 & 0.18 & 0.11 & 48.77 \\
\hline & $43-53$ & 3.62 & 9.84 & 4.98 & 4.56 & 2.01 & 0.42 & 0.18 & 0.03 & 0.03 & 25.68 \\
\hline & $53-90$ & 3.25 & 8.31 & 4.46 & 3.81 & 1.12 & 0.28 & 0.15 & 0.06 & 0.00 & 21.44 \\
\hline & $\sum$ & 14.92 & 37.45 & 19.20 & 17.43 & 7.60 & 2.17 & 0.81 & 0.28 & 0.15 & 100.00 \\
\hline
\end{tabular}

Source: developed by the author based on the data derived from the insurer.

Figure 3 presents the average value of claims paid in separate age groups of the insured.

As one can see in Figure 3, the highest average value of payments was observed in the group of the insured under the age of 25 years and from 25 to 28 years. The analysis of the data from Table 3 allows us to note that in each of the studied years the largest proportion of damages were payments with a value from 1 to 3 thousand zlotys (approx. 38\% of total compensation) and payments from 3 to 5 thousand zlotys and from 5 to 10 thousand zlotys (approx. 20\% of total compensation). The structure of values of the compensation paid to the insured in the group of up to 25 years old is different from the structure of payments in other age groups. Persons under the age of 25 years cause the most (29\%) damages worth between 5 and 10 thousand zlotys. In other age groups 
most common are the payments (from $36 \%$ to $40 \%$ ) with value from 1 to 3 thousand zlotys. In comparison to the other groups among drivers aged 25 or younger there are also quite a lot of damages with a value of 1 thousand zlotys $19 \%$. For example, the payout structure of different age groups studied for the first years is shown in Figure 4.

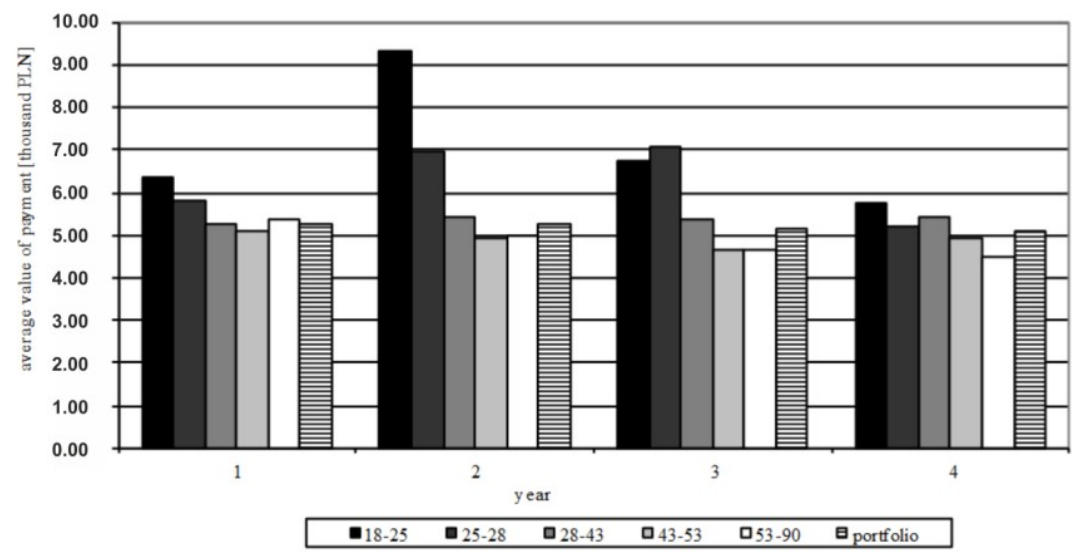

Figure 3. The average value of claims paid in the motor hull liability insurance portfolio in the years analyzed, according to the age of insured

Source: own elaboration.

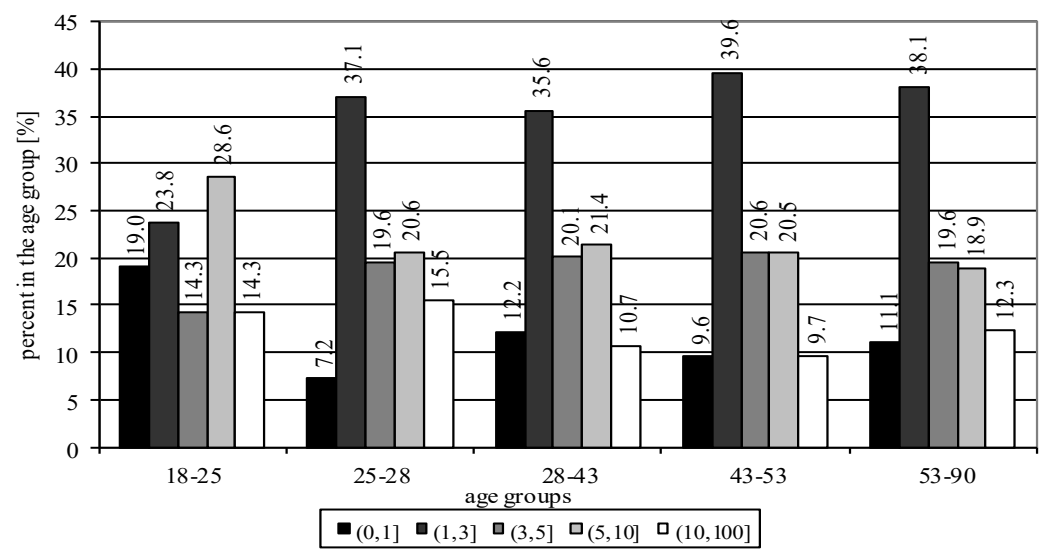

Figure 4. The structure of claims paid in the motor hull liability insurance portfolio in the first year, according to the age of insured

Source: own elaboration. 
The analysis of the number and value of claims paid confirms the justification of taking into account in ratemaking the age of the insured, especially for drivers up to 25 years. In motor insurance, the individual premium net in the period $t+1$ is determined by the equation (Szymańska 2014):

$$
\Pi(X, K)=(E X) \cdot(E K) \cdot b_{t+1}
$$

where $\Pi(X, K)$ - individual net premium in period $t+1, E X$ - the expected value of a single loss in the portfolio, $E K$ - the expected number of claims for individual insurance portfolio, $b_{t+1}-$ the rate of premium in period $t+1$. In actuarial literature the independence of random variables of the amount and number of damages is assumed.

The aim of this study is to determine the coefficient $b_{t+1}$ constituting the increase or discount of the premium dependent on the age of the insured. Net premiums were estimated using the Bühlmann-Straub model. Models based on the theory of credibility do not require assumptions about the form of the random variable describing the size of individual loss in the portfolio and the values of the parameters of this distribution.

The net premium is determined by multiplying the expected value of the estimated payments by the Bühlmann-Straub model in particular age groups of the insured (based on data from Table 4) and the expected number of claims is also estimated based on the Bühlmann-Straub model (see the data in Table 6). Two cases were considered: when the contribution of the credibility is a heterogeneous or homogeneous predictor of the net premium. Tables 5 and 7 show the results of the estimation. Premium rates in different age groups were calculated as the ratio of the net premiums in a given age group and the net premium in the portfolio. The values of the net premiums and net premium rates are shown in Table 8.

Table 4. The average value of compensation paid [thous. of zlotys] in the portfolio according to the age of the insured in the years analyzed

\begin{tabular}{|c|c|c|c|c|c|c|c|c|}
\hline \multirow{2}{*}{$\begin{array}{c}i \text { (age } \\
\text { group) }\end{array}$} & \multicolumn{9}{|c|}{$j$ (year) } \\
\cline { 2 - 9 } & $X_{i j}$ & $w_{i j}[\%]$ & $X_{i j}$ & $w_{i j}[\%]$ & $X_{i j}$ & $w_{i j}[\%]$ & $X_{i j}$ & $w_{i j}[\%]$ \\
\hline 1 & 6.38 & 0.83 & 9.34 & 0.38 & 6.75 & 0.81 & 5.76 & 0.97 \\
\hline 2 & 5.84 & 3.82 & 6.96 & 3.47 & 7.09 & 4.09 & 5.19 & 3.13 \\
\hline 3 & 5.27 & 48.43 & 5.45 & 48.69 & 5.37 & 50.23 & 5.44 & 48.77 \\
\hline 4 & 5.09 & 28.43 & 4.92 & 27.29 & 4.63 & 24.50 & 4.93 & 25.68 \\
\hline 5 & 5.38 & 18.50 & 5.01 & 20.17 & 4.66 & 20.37 & 4.50 & 21.44 \\
\hline
\end{tabular}

Notes: $X_{i j}-$ the average value of claim paid in the $i$-th group in period $j$ [thous. zlotys], $w_{i j}-$ the share of policies in $i$-th group of the portfolio in period $j[\%], 1-$ group of insured at the age of 18-25 years, 2 - group of insured at the age of 25-28 years, 3 - group of insured at the age of 28-43 years, 4 - group of insured at the age of 43-53 years, 5- group of insured at the age of 53-90 years.

Source: own calculations. 
Table 5. Coefficients of credibility, credibility premium [thous. of zlotys] and estimation errors according to age groups

\begin{tabular}{|c|c|c|c|c|c|}
\hline$i$ & $Z_{i}$ & $\tilde{m}_{i}^{*}$ & $\tilde{m}_{i}$ & $M S E_{i}^{*}$ & $M S E_{i}$ \\
\hline 1 & 0.29 & 5.73 & 5.60 & 0.18 & 0.15 \\
\hline 2 & 0.66 & 6.04 & 5.98 & 0.08 & 0.07 \\
\hline 3 & 0.96 & 5.40 & 5.39 & 0.01 & 0.01 \\
\hline 4 & 0.93 & 4.89 & 4.88 & 0.01 & 0.01 \\
\hline 5 & 0.92 & 4.82 & 4.80 & 0.02 & 0.02 \\
\hline
\end{tabular}

Source: own calculations.

Table 6. The average number of claims in the portfolio according to the age of the insured in the years analyzed

\begin{tabular}{|c|c|c|c|c|c|c|c|c|}
\hline \multirow{2}{*}{$\begin{array}{c}i \text { (age } \\
\text { group) }\end{array}$} & \multicolumn{9}{|c|}{$j$ (year) } \\
\hline & \multicolumn{2}{|c|}{1} & \multicolumn{2}{|c|}{2} & \multicolumn{2}{|c|}{3} & \multicolumn{2}{|c|}{4} \\
\hline & $K_{i j}$ & $w_{i j}$ & $K_{i j}$ & $w_{i j}$ & $K_{i j}$ & $w_{i j}$ & $K_{i j}$ & $w_{i j}$ \\
\hline 1 & 0.21 & 0.39 & 0.16 & 0.25 & 0.19 & 0.52 & 0.23 & 0.52 \\
\hline 2 & 0.15 & 2.75 & 0.18 & 2.41 & 0.19 & 2.76 & 0.17 & 2.13 \\
\hline 3 & 0.11 & 46.26 & 0.12 & 46.38 & 0.14 & 46.55 & 0.12 & 46.28 \\
\hline 4 & 0.11 & 27.59 & 0.12 & 26.90 & 0.12 & 25.30 & 0.11 & 24.83 \\
\hline 5 & 0.09 & 23.01 & 0.10 & 24.06 & 0.10 & 24.87 & 0.09 & 26.24 \\
\hline
\end{tabular}

Notes: $K_{i j}$ - the average number of claims in the $i$-th group in period $j, w_{i j}-$ the share of policies in $i$-th group of the portfolio in period $j[\%], 1$ - group of insured at the age of 18-25 years, 2 - group of insured at the age of 25-28 years , 3 - group of insured at the age of 28-43 years, 4 - group of insured at the age of 43-53 years, 5 - group of insured at the age of 53-90 years.

Source: own calculations.

Table 7. Coefficients of credibility, number of damages estimated by means of the credibility method and estimation errors for age groups of the insured

\begin{tabular}{|c|c|c|c|c|c|}
\hline$i$ & $Z_{i}$ & ${ }^{K} \tilde{m}_{i}^{*}$ & ${ }^{K} \tilde{m}_{i}$ & $M S E_{i}^{*}$ & $M S E_{i}$ \\
\hline 1 & 0.29 & 0.1510 & 0.1403 & 0.0003 & 0.0003 \\
\hline 2 & 0.69 & 0.1617 & 0.1571 & 0.0001 & 0.0001 \\
\hline 3 & 0.98 & 0.1233 & 0.1229 & 0.0000 & 0.0000 \\
\hline 4 & 0.96 & 0.1162 & 0.1156 & 0.0000 & 0.0000 \\
\hline 5 & 0.96 & 0.0959 & 0.0953 & 0.0000 & 0.0000 \\
\hline
\end{tabular}

Source: own calculations.

Taking into account equations (13), (8) and (9), the value of the net premium was determined from the formulas:

$$
\begin{aligned}
& \Pi_{i}(X, K)=\tilde{m}_{i} \cdot{ }^{K} \tilde{m}_{i} \cdot{ }_{i} b_{t+1} \\
& \Pi_{i}(X, K)=\tilde{m}_{i}^{*} \cdot{ }^{K} \tilde{m}_{i}^{*} \cdot{ }_{i} b_{t+1}^{*}
\end{aligned}
$$


The value of the net premiums is presented in Table 8 .

Table 8. Net premiums and contributions of net premiums according to the age of the insured

\begin{tabular}{|c|c|c|c|c|}
\hline \multirow{2}{*}{ Age [years] } & \multicolumn{2}{|c|}{ Net premium [thous. of zlotys] } & \multicolumn{2}{c|}{ Net premium rate in group $i$ [\%] } \\
\cline { 2 - 5 } & $\tilde{m}_{i}{ }^{*} \cdot{ }^{K} \tilde{m}_{i}^{*}$ & $\tilde{m}_{i} \cdot{ }^{K} \widetilde{m}_{i}$ & ${ }_{i} b_{t+1}^{*}$ & ${ }_{i} b_{t+1}$ \\
\hline $18-25$ & 0.86462 & 0.78597 & 124.15 & 131.93 \\
\hline $25-28$ & 0.97624 & 0.93896 & 140.18 & 157.61 \\
\hline $28-43$ & 0.66516 & 0.66249 & 95.51 & 111.21 \\
\hline $43-53$ & 0.56802 & 0.56365 & 81.56 & 94.61 \\
\hline $53-90$ & 0.46203 & 0.45756 & 66.34 & 76.81 \\
\hline portfolio & 0.69642 & 0.59573 & 100.00 & 100.00 \\
\hline
\end{tabular}

Source: own calculations.

\section{CONCLUSIONS}

The analysis of the number and value of claims paid in the analyzed portfolio justifies the use of the age of the insured as one of ratemaking variables. Insured persons aged from 18 to 25 years and from 25 to 28 years, on average, cause more damage per year with higher average value, and therefore should pay higher premiums. The estimation results indicate a contribution rate of between $125 \%$ to $132 \%$ of the basic premium for drivers under the age of 25 years. In the analyzed insurance company in the years investigated, the insured under the age of 25 years paid $300 \%$ of the basic premium, if they bought insurance for the first time in this company and $200 \%$ of the basic premium on the continuation of insurance. According to the estimation method, people aged from 25 to 28 should pay the highest contribution rate of $140 \%$ to $157 \%$. In the insurance company analyzed, drivers aged 25 to 28 years who took out insurance for the first time in the company paying the rate of $170 \%$ of the basic premium, on the continuation the rate was $130 \%$ of the premium. The group, which according to estimates should not have increases in premiums but a discount (5-10\%), are the insured at the age from 43 to 53 years. In the studied company they were at a $10 \%$ rise in the premium unless they signed a declaration about not sharing a vehicle with any person aged up to 25 years. Drivers aged 28 to 43 years should have a small increase of premium of approx. $10 \%$. The study shows that people over 53 years of age could have a small discount. However, in the analyzed insurance company there were no discounts due to the age of the insured. There also was no discount due to the time of the possession of driving license. 


\section{REFERENCES}

Antonio K., Valdez E. (2012), Statistical concepts of a priori and a posteriori classification in insurance, "AStA Adv Stat Anal" 96, pp.187-224.

Bühlmann H. (1967), Experience Rating and Credibility, "ASTIN Bulletin” 4 (3), pp. 199-207.

Bühlmann H., Straub E. (1970), Glaubwürdigkeit für Schadensätze, "Mitteilungen der Vereiningung scheizerischer Vesicherungsmathematiker", pp. 111-133.

Daykin C.D., Pentiäinen T., Pesonen M. (1994), Practical Risk Theory for Actuaries, Chapman \& Hall, London.

Denuit M., Marechal X., Pitrebois S., Walhin J.F. (2007), Actuarial Modelling of Claim Counts. Risk classification, Credability and Bonus-Malus Systems, J. Wiley \& Sons, England.

Jasiulewicz H. (2005), Teoria zaufania. Modele aktuarialne, Wyd. AE im. Oskara Langego we Wrocławiu, Wrocław.

Kaas R., Goovaerts M., Dhaene J., Denuit M. (2001), Modern Actuarial Risk Theory, Kluwer, Boston.

Krzyśko M. (1996), Statystyka Matematyczna, Wyd. Naukowe UAM, Poznań.

Kowalczyk P., Poprawska E., Ronka-Chmielowiec W. (2006), Metody aktuarialne, PWN, Warszawa.

Lemaire J. (1995), Bonus-Malus Systems in Automobile Insurance, Kluwer, Boston.

Szymańska A. (2014), Statystyczna analiza systemów bonus-malus w ubezpieczeniach komunikacyjnych, Wyd. UŁ, Łódź.

Anna Szymańska

\section{ZASTOSOWANIE MODELU BÜHLMANNA-STRAUBA DO ESTYMACJI STAWEK SKLADKI NETTO ZALEŻNYCH OD WIEKU UBEZPIECZONYCH W UBEZPIECZENIU AUTOCASCO}

Streszczenie: Jedną $\mathrm{z}$ podstawowych zmiennych taryfikacyjnych wykorzystywanych w procesie kalkulacji składki w ubezpieczeniach komunikacyjnych AC jest wiek ubezpieczonego. W ubezpieczeniach tego typu oferowanych przez ubezpieczycieli prowadzących działalność na polskim rynku zmienna ta jest uwzględniana w taryfikacji poprzez zwyżki i zniżki w składce przypisanej nazywane stawkami składki netto. Celem pracy jest zaproponowanie metody estymacji stawek składki netto w grupach portfela ubezpieczeń komunikacyjnych AC osób fizycznych utworzonych według wieku ubezpieczonych. Do szacowania składki wykorzystano jeden z modeli teorii największej wiarygodności tzw. model Bủlmanna-Strauba.

Slowa kluczowe: taryfikacja a posteriori, teoria największej wiarygodności, ubezpieczenie autocasco. 